\title{
A Feasibility of Land Consolidation in Kigezi Region, South Western Uganda (A Solution to Land Fragmentation, Land Shortage, Farmer's Productivity and Economic Development)
}

\author{
George Stanley Kinyata (PhD), Nafiu Lukman Abiodun (PhD)* \\ Department of Economics and Statistics, Kabale University, Uganda
}

*Corresponding Author: Nafiu Lukman Abiodun (PhD), Department of Economics and Statistics, Kabale University, Uganda

\begin{abstract}
The cooperative societies which have existed in Uganda for longtime have been mainly on Agricultural products and marketing and not necessarily on land use management and productivity. These are not on increasing yields and productivity per inputs applied, not on land size and not on problems of land fragmentation and economic efficiency in Agriculture, which this article is about. This article therefore, is about land use management and the reverse of the effects of land fragmentation and their related problems such as land conflicts, population pressure, poverty, productivity, land scarcity and then the solutions to solve these problems. The idea of land consolidation is being introduced in the article as putting together plots or pieces of land which exist in Kigezi Region, with the aim of making them economically viable and more productive per unit of investment. This need not change the amount of land owned and controlled by individuals, and therefore not necessarily an instrument of social justice but an answer to land scarcity and fragmentation in Kigezi Region. The article compares the benefits of the land under fragmentation and the land under consolidation systems and recommends strategies to transform Kigezi Region's informal and subsistence farming to modern, commercial agriculture to achieve food security and increase incomes of the population and economic development of the area.
\end{abstract}

Keywords: Land; Consolidation; Fragmentation; Shortage; Farmers; Productivity.

\section{INTRODUCTION}

Land is the main asset for livelihood of many African people on which development and general social progress is based (Bizoza and Havugimana, 2013 and Nilsson, 2017). With increasing population, the problem of land scarcity and land fragmentation continues to affect development in Kigezi Region and subsequently affecting food security and crop production to allow them have food surplus to generate income. The Driver of land reform policy in Uganda of 2013, should have been to improve land use management and to reverse the adverse effects of land fragmentation and related problems concerning land disputes prevailing in Uganda. This was not covered in the land reform policy of 2013. The method of reversing the effect of land fragmentation in the country is the application of land use consolidation which should have been an answer to the societies where there are lots of land fragmentation (Deininger et al., 2012) This was not the case for Kigezi region.

The land use consolidation should be regarded as one of the policies in Kigezi Region to improve farm holdings, having arable land on big scale. This article would like to introduce the set up and running of a land use consolidation programme in Kigezi Region for Economic development purposes, because cooperatives in the country have been mainly on agricultural products and marketing and not necessarily on land use management and production. They are not increasing yield and productivity per inputs applied, not on land size, not on the problem of land fragmentation and economic efficiency in agriculture. This article is therefore about the state of land fragmentation in Kigezi Region, its effects and the introduction of land consolidation in the region.

Kigezi Region is situated in the south western Uganda. A very hilly, cold and mountainous region, bordering the Republic of Rwanda and Democratic Republic of Congo. Because of its hills, mountains and cold weather, people call it the Switzerland of Africa. It is full of Agricultural Terraces and a home of the world famous mountain guerillas. 
A Feasibility of Land Consolidation in Kigezi Region, South Western Uganda (A Solution to Land Fragmentation, Land Shortage, Farmer's Productivity and Economic Development)

According to National Census of 2014 and Uganda Bureau of Statistics (UBOS) of 2016, the region has a population of about 1.5 million people from the following 6 Districts:

Table1. Districts in Kigezi Region and their Population

\begin{tabular}{|l|l|l|}
\hline S/N & District & Population \\
\hline 1 & Kabale & 255,600 \\
\hline 2 & Kisoro & 309,600 \\
\hline 3 & Kanungu & 273,000 \\
\hline 4 & Rukungiri & 330,700 \\
\hline 5 & Rubanda & 206,600 \\
\hline 6 & Rukiga & 104,700 \\
\hline & Total & $\mathbf{1 . 4 8 0 , 2 0 0}$ \\
\hline
\end{tabular}

Source: UBOS (2016)

People in Kigezi Region grow mainly the following crops successfully; Coffee, Tea, Maize, Irish potatoes, Bananas, Peas, Sweet potatoes, Beans, Ground nuts, Millet, Sorghum, Dairy products, Cassava, Rice, etc.

Some of these crops are grown more in some districts than in others. Mono-cropping, zoning them in areas according to better yields produced per season would be encouraged with assistance of Agriculturalists and ministries officials. Some of these crops are for exports, such as coffee and tea, dairy products etc. But others are for domestic consumption but can also be sold to neighboring countries.

The mono-cropping and methods of implementation of land consolidation will be by producer cooperatives or associations. Because of the geographical situation, population pressure and land fragmentation, massive migration of Kigezi population over many years have been going on to other parts of Uganda mainly to Ankole, Tooro, Bunyoro, Buganda after exhausting areas in Kigezi such as Kinkizi (now Kanungu), Rukungiri etc.

The following are land problems in Kigezi Region:

* Land fragmentation

* Scarcity and tiny size of arable land

* Population pressure

* Old cultural and traditional practices (division of land)

* Recurrent soil erosion on steep hill sides

* Soil acidity, among others

All these factors make land in Kigezi less productive for farmers to generate more income, food surplus to sell for revenue and get out of poverty. The problem therefore is how to increase the size of agricultural land or increase productivity of farmers and incomes of the people of Kigezi. Some of these problems of land fragmentation can be solved by land consolidation which should go hand in hand with rural development and land productivity. This is why an application of land use consolidation in Kigezi Region is recommended in this article.

Land use consolidation is being introduced in Kigezi Region as a tool to improve farm management and holdings to arable land on big scale, allowing cultivation of one crop on large scale but also rational use of inputs and pesticides, including the increase of acreage in terms of hectares of plots put together each season to grow each priority crops and move away from land fragmentation that creates land too small and uneconomically viable, reducing already limited arable land. Land consolidation would therefore lead to Economic development of the region. Economic development in the area has been defined in the article as the process by which a community of farmers In Kigezi raises its living standards because of the new adapted policy of land use consolidation proposed programme which will be measured in terms of increase of income from the sale of surplus food crops gotten after consolidating the land. It will also be measured after looking at the savings, farmers will be able to make and the investments realized, leading to the development of economic wealth of Kigezi Region, for the wellbeing of its inhabitants. The article considers economic development as a sustainable increase in living standards that implies increased per capita income, a process by which real Gross 
National Product increases quantitatively and qualitatively over every long time in the region. It can also be measured by an increase in things which improve the quality of life of human being such as houses, food, medical care etc.

In Kigezi region therefore, there is scarcity and tiny size of agricultural holdings which are the results of both the population pressure and land fragmentation that has been practiced for long time with old and tradition cultural practices where peasants used and some of them still use to divide their land among their sons but as time goes on, the pieces of land become smaller and smaller as the population goes on increasing and with recurrent soil erosion on steep hill sides, making arable land less productive.

\section{LITERATURE REVIEWS}

The problem of land fragmentation is therefore one of the world's concern and also of present and future Ugandan problem number one which needs a quick solution that has been neglected until such problem is becoming endemic, creating starvation, erosion, and poverty, even land desertification in Kigezi Region. Land use management and the reversal of the effects of land fragmentations and their related land problems such as land conflicts are what the article is about. The solution is to solve the greatest problem, namely land scarcity, poverty, combined with population pressure which are interrelated in Kigezi Region. Poverty occurs where there are large increase in population and is less prevalent where population is stable. These are both related to costs and living standards.The solution to this problem is land use consolidation. The increase of acres and hectares of pieces of land put together each season in orderto grow each priority crop is the answer. This encourages crops specialization, leading to economies of scale and commercialization of agricultural products, increasing productivity and crop yield, bringing food crop surplus to sell to market for money hence income of the people.

The land consolidation will generally be considered as putting small plots or pieces of land which exist in Kigezi Region, with the aim of making them economically viable and more productive per unit of investment. This need not change the amount of land owned and controlled by individuals, and therefore not necessarily an instrument for social justice. It is just an answer to Kigezi Region people where there has been lots of land fragmentation (Blarel et al., 1992 and Deininger et al., 2012).

Land consolidation is not a new concept in the world for economic development initiatives. It has been practiced in many countries such as Europe since the Middle Ages until $19^{\text {th }}$ and $20^{\text {th }}$ centuries (Vitikainen, 2004). Practices of land consolidation are found today in Germany, Netherland, France, Belgium, Austria and Switzerland and Finland, Norway and Sweden. Also, there has been considerable land consolidation in Eastern European countries after the reforms from socialist production systems that had resulted in fragmented lands. In the whole of Western Europe by early 1990's land consolidation involved a quarter of all cultivated land in excess of 38 million hectares of arable land. In sub-Sahara Africa, land is a fundamental issue for economic development, food security and poverty reduction (Cotula et al., 2006). However, in many African countries, including Uganda, land is increasingly becoming scarce due to a variety of pressures, including population growth.

In Europe and other developed countries, the need for land consolidation is becoming less and less and not as it was in the past. The emphasis now is to create large farms which have become priorities. The demand for land consolidation is now new in developing countries and it is mainly caused by landlessness, poverty, joint-ownership, limited funds, and lack of political will. It has come when fragmentation of the land is at its highest in Africa. Land is best when it is in production and in active use. Fragmentation of arable land is about to reach the abandonment stage and to increase production in Kigezi comes with the land consolidation to alter fragmentation and allow farmers to benefit from government various services such as: Efficient delivery of inputs, proximity extension services, postharvest handling and storage facilities, irrigation and mechanization by public and private stakeholders, concentrated market for inputs and outputs etc. These are benefits that land consolidation would bring to the Kigezi farmers if the system is implemented.

Land consolidation has worked in Rwanda and in very many other countries. This is different from Ujamaa policy of Tanzania which succeeded only in bringing people to live together in villages but not transformation of production structures, increase productivity of rural areas. Ujamaa enterprises 
were too small to allow scale economies. People had no training, no experience in large scale production. Ujamaa policy, unlike land consolidation policy this article is recommending, did not lead to any significant increase in productivity or surplus flow from agriculture in Tanzania. In view of those considerations, very many land consolidation and land reform policies have been implemented to reduce land fragmentation in developed and in developing countries. When asked some farmers in Kabale District in Kigezi Region, the reasons why they would prefer land use consolidation to land fragmentation, most of them said, "From land consolidation, we shall get free fertilizers, improved seed grants, zero soil erosion, mono-cropping practice, common fight against pests, land leveling and management etc. They said that every farmer who participates in land consolidation would get a package of incentives from crop intensification programme. By consolidating the land, farmers will be able to protect and enlarge it. By acquiring new agricultural techniques and methods, farmers will be able to increase productivity of their land. By applying the incentive package, the farmers will be able to double or quadruple the harvest of their prioritized crops, contribute to the economic growth of Kigezi farmers and therefore to the development of the region. The region needs therefore land use consolidation policy to improve the farmers' innovation and hence living standards.

The adoption of land consolidation by farmers in Kigezi would lead to growth of larger farms and production of higher family incomes and that productivity would increase and a number of small pieces of land decreases (Lerman and Cimpoies, 2006).

Land Use Consolidation (LUC) should be one of the policies to improve farm holdings in allowing arable land on a big scale, cultivation of one crop on large scales and rational use of inputs and pesticides.

Table2. Land Fragmentation and Consolidation Comparisons

\begin{tabular}{|l|l|}
\hline When the land is under fragmentation system & When the land is under consolidation system \\
\hline 1. Laws of inheritance & 1. Increased commercialization \\
2. Small sizes of landholdings & 2. Increased net income for a farmer \\
3. Increasing population pressure & 3. Improving agricultural productivity \\
4. Land scarcity or in small sizes & 4. Increased more investment \\
5. Food insecurity/food deficit & 5. Sufficient food production \\
6. Poor land management & 6. Food surplus for sale \\
7. Low labour productivity & 7. Raised productivity in small fragmented holdings \\
8. Poor productivity of land & 8. Growth of priority food crops \\
9. Use of land unsustainably & 9. Increased farmers productivity \\
10. Little structural transformation & 10. One crop on large scale \\
11. Small multiple ownership & 11. Expansion of arable land \\
12. Multiple subdivisions & 12. Rational use of inputs and pesticides by farmers \\
13. Negative farms productivity & 13. Poverty reduced \\
14. Poor farm practices & 14. Reversing fragmentation activities \\
15. Low level use of farm inputs & 15. Improved land use management \\
16. No mechanization can take place & 16. Increased yield and productivity per input applied \\
16. High transport cost. & 17. Increased income and standards of livings of farmers \\
& 18. Mono-cropping practice and common fight against \\
& pests by organized farmers \\
& 19. Increased incomes and profits per acre \\
& 20. Proximity extension services, concentrated markets for \\
& inputs, efficient delivery. \\
\hline
\end{tabular}

Table 2 shows the differences between the two systems for making decisions by farmers and government officials when the two systems are working.

Many land reform measures have been obstructed at the policy making stage, and then sentenced to a slow death in execution by unsystematic bureaucracy. This is what has happened in Uganda for the one of 2013land policy. Because there was no determination of the existing formal and informal structure in land, which normally reduces the conflicts between individual rights and the state rights protected. The government should have thought of this land policy that responds to the needs of the people as land gets smaller and yields diminishes. The question arises, who is to look after the interests and welfare of the starving rural people? While ruthless officials often determines their fate!

According to Abubakari et al. (2016) land consolidation allows farmers to benefit from the various services such as: 
1. Efficient delivery of inputs (e.g. improve seeds, fertilizers)

2. Proximity extension services

3. Post-harvest handling and storage facilities

4. Irrigation and mechanization by public and privet stakeholders

5. Concentrated markets for inputs and outputs

6. Increased productivity

7. Increased income and profits per acre

8. Employment generation

Land fragmentation is regarded as a feature of less developed agricultural systems and a major obstacle to agricultural development because it hinders agricultural mechanization, causes inefficiencies in production and involves large costs to alleviate its effects. That is why land consolidation and land reform policies have been introduced in many countries to reduce fragmentation in Africa such as Botswana, Cape Verde, and Maldives, Kenya, Rwanda etc.

The major causes of land fragmentation have been attributed to increase in population, laws of inheritance, poverty, landlessness, etc. Laurance et al. (2007) and fragmentation is a disease of land tenure. According to Jacoby and Minten (2007), subdivisions and excessive fragmentation are inherent defects of old peasant communities. Though they still exist in many parts of the world where peasants are reluctant to change from the past. The increase of landlessness is a problem of fragmentation, when the fragmented land is consolidated, it happens that people owning insufficient land to create an economic unit are displaced, and become landless in the process and move to cities. Land consolidation is the answer to the societies where there are lots of land fragmentation like in Kigezi Region where farm management issue is a problem. Among the main factors that have contributed to subdivisions and land fragmentation is the traditional system of inheritance of land where it is the divided and bequeathed to sons. As the population increases not only the size of holdings fall, but they are increasingly fragmented into smaller plots, scattered all over a wide area.

The driver of land consolidation in Uganda should largely be the need to improve land use management and to reverse the effects of land fragmentation and make farming economically viable and respond to the needs of the people and population pressure, since one of the world's greatest problem is poverty combined with population pressure. The land fragmentation is regarded as a feature of less developed agricultural system and a major obstacle to agricultural development, because it hinders agricultural mechanization, causes inefficiencies in production, results in small and uneconomic size of operational holdings. As the population increases, not only does the size of holdings fall, but they are increasingly fragmented into smaller and smaller pieces of land in Kigezi region.

The study has used a simplified, voluntary land use consolidated model where by farmers in a given area grow the priority food crops in groups. Keeping their land rights intact, setup and run land use consolidation programme in the whole Kigezi region would be the answer.

Due to assumption that land use fragmentation has a negative impact on agricultural productivity, reorganization of the available space and technological innovations are necessary. In order to ensure food security for increasing population by putting together small plots orpieces of land, manage the land and use it in consolidated manner so that the land can give more yields.

The possession of land tittles also helps to improve tenure security and makes land owners feel confident to make long term investments in their land which may be a stimulus to the enhancement of land productivity.

Fragmentation influences negative farm productivity tiny land sizes and causes land scarcity. It hinders mechanization and drives to poor farming practices. It causes inefficient production, food insecurity. It involves large costs to alleviate its effects. It reduces farmer's net income, causes poverty, food deficit. It cannot get sufficient yields due to undersized units of land, poor farming 
practices and low level in the use of fertilizers and other inputs. No structural economic transformation can take place in such circumstances. Cultural inheritance of land division reduces land availability, lowers labour productivity etc.

According to the agronomists who were consulted after land use consolidation proposal during this study, they said that land consolidation raises productivity and yields more than original 4 times. Asked the reasons behind that increase, most of them mentioned availability of fertilizers supplied to organized group, improve seed grants, zero soil erosion, mono-cropping practice, common fight against pests and common land leveling etc. They gave examples of Rwanda where maize production had more than tripled because of land consolidation, production of beans doubled, harvest of Irish potatoes increased by 4.4 times and said that when fragmented land is reorganized and combined, it becomes a productive farm and cuts off production costs.

The agronomists added that farmers who own bigger land and exploit it properly; using adequate techniques get food surplus for sale and can generate more income and improve the livelihood of their families.

However, there are some challenges which may face land consolidation program me and need government attention:

1. Limited rural infrastructure

2. Climate changes and high micro climatic variability in production zones.

3. High operational costs and lack of agricultural credit.

4. Fluctuations in global food prices/dynamics in trading regulations

5. Water scarcity and distribution in rural areas

6. Population pressure on land and land being too small and outspread. People resistant to change

7. Lack of energy, transport and poor roads causing costs to be high

8. Challenges in marketing output

In addition to land fragmentation, Zhou (1999) said that the relief of the region exacerbates soil erosion in Kigezi, where $50 \%$ of all the farms are subject to erosion, plus over cultivation which is one of the causes of fall in agricultural productivity in Kigezi region.

\section{CONCLUSION AND RECOMMENDATIONS}

The government of Uganda has not implemented properly and in full the agricultural policy of 2013. It should have pursued a private sector-led and market-oriented economy. To do this, it should work on the constraints that have been identified in this article, which hinder private sector from increasing investment in the sector. Agricultural production zones or group cropping through commodity-based approach, that is to say, commodities that are best suited for each zone as identified in the article should be supported for food security and for commercialization. Development of commodity valuechain in different zones in Kigezi Region should be supported in order to develop viable agrobusiness centers, groups in different areas of Kigezi Region. Key agricultural resources should be used sustainably, well managed to support adequate production for the current and future generations.

In order to have a competitive, profitable and sustainable agricultural sector,

Uganda should transform informal and subsistence farming to modern, commercial agriculture in order to achieve food security and house hold incomes of the population. To increase house hold income in an economy where the prices will be determined by the market, Kigezi region must expand production, increase incomes of the people from organized and well managed land so that farms can improve the volume of their output, improve quality, access to recommended technology to raise farm productivity under land use consolidation.

There should be some strategies to boost production and productivity by skilling and training farmers to promote large scale farming enterprises, block farming and be able to compete regionally and nationally. 
Land use consolidation programme once introduced will enhance education and sensitize farmers towards mono-cropping and prioritizing crops in the region and country.

Government and other stakeholders will provide water through irrigation schemes to support crop farming during the dry season to keep sustainability of crop production.

Determination of priority crops for each Agro-climatic zone should be done jointly with farmers, District Officials and Agriculturalists compiling reports showing productivity increase of each prioritized crop.

The government should provide the feedback and capacity building to farmers on how to apply inputs such as fertilizers to support land productivity to increase the outputs/yield and improve economic development of the region and the country at large.

\section{REFERENCES}

[1] Abubakari Z., Van Der Molen P., Bennett R. M. and Kuusaana E. D. (2016). Land Consolidation, Customary Land and Ghana's Northern Savannah Ecological Zone: An Evaluation of the Possibilities and Pitfalls. Land Use Policy. Volume 54, pp 386 - 398.

[2] Ali D. A., Deininger K. and Ronchi L. (2019). Costs and Benefits of Land Fragmentation: Evidence from Rwanda. World Bank, Washington DC.

[3] Bizoza, A. R. and Havugimana, J. M. (2013). Land Use Consolidation in Rwanda: A Case Study of Nyanza District, Southern Province.International Journal of Sustainable Land Use and Urban Planning. Vol. 1, No. 1, pp $64-75$.

[4] Blarel B., Hazell P., Place F. and Quiggin J. (1992). "The Economics of Farm Fragmentation: Evidence from Ghana and Rwanda." World Bank Economic Review, 6(2), 233-254.

[5] Cotula L., Toulmin C. and Quan J. (2006). Better Land Access for the Rural Poor: Lessons from Experience and Challenges Ahead. IIIED, FAO. ISBN: 1-84369-632-0. Russell Press, Indonesia.

[6] Deininger K., Savastano S. and Carletto C. (2012). "Land Fragmentation, Cropland Abandonment and Land Market Operation in Albania".The World Bank Research GroupAgriculture and Rural Development Team. Policy Research Works Paper6032. http://econ.worldbank.org.

[7] Jacoby, H.and Minten, B. (2007). Is Land Titling in Sub-Saharan Africa Cost-Effective? Evidence from Madagascar. World Bank Economic Review. Vol. 21, Issue 3, pp 461-485.

[8] Laurance W. F., Nscinmento H. E. M., Laurance S. G., Andrade A., Ewers R. M., Harms K. E. (2007) Habitat Fragmentation, Variable Edge Effects, and the Landscape-Divergence Hypothesis. PloS ONE 2(10): e1017. http://doi.org/10.1371/journal.pone.0001017.

[9] Lerman, Z. and Cimpoies, D. (2006). Land Consolidation as a Factor for Rural Development in Moldova. Journal of Europe-Asia Studies. Volume 58, Issue 3, pp 439-455.

[10] Nilsson, P. (2017). "Assessing the Role of Land Use Consolidation for Consumption Growth in Rwanda.The Royal Institute of Technology Center of Excellence for Science and Innovation Studies (CESIS). http://www.cesis.se

[11] Uganda Bureau of Statistics UBOS (2016). The National Population and Census 2014 - Main Report, Kampala, Uganda.

[12] Vitikainen, A. (2004). An overview of Land Consolidation in Europe. Nordic Journal of Surveying and Real Estate Research. Vol. 1, pp 25-43.

[13] Zhou, J. M. (1999). How to Carry Out Land Consolidation. International European University Institute, Department of Economics. Italy. http://www.iue.it/ECO/WP-Texts/ECO99-1.pdf./3.3.2002.

Citation: George Stanley Kinyata (PhD), Nafiu Lukman Abiodun (PhD). "A Feasibility of Land Consolidation in Kigezi Region, South Western Uganda (A Solution to Land Fragmentation, Land Shortage, Farmer's Productivity and Economic Development)" International Journal of Research in Sociology and Anthropology (IJRSA), vol 6, no. 3, 2020, pp. 09-15. doi: https://doi.org/10.20431/2454-8677.0603002.

Copyright: (C) 2020 Authors. This is an open-access article distributed under the terms of the Creative Commons Attribution License, which permits unrestricted use, distribution, and reproduction in any medium, provided the original author and source are credited. 